\title{
SYNTHESIS AND CHARACTERIZATION OF STRUCTURAL NANOCOMPOSITE TITANIUM DIOXIDE COPPER-DOPED USING THE IMPREGNATION METHOD
}

\author{
La Ode Asmin*, La Isa \\ Department Mathematics and Natural Sciences, IAIN Kendari, Southeast Sulawesi, Indonesia \\ *Corresponding Author Email: fisikakuanta@gmail.com
}

Received: 28 March 2020

Revised: 1 April 2020

Accepted: 4 April 2020

Online: 26 April 2020

Published: 30 April 2020

SPEKTRA: Jurnal Fisika dan Aplikasinya

p-ISSN: 2541-3384

e-ISSN: 2541-3392

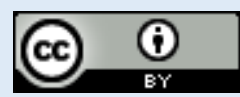

\begin{abstract}
Nanocomposite Titanium Dioxide $\left(\mathrm{TiO}_{2}\right)$ doped Copper $(\mathrm{Cu}), \mathrm{Cu}-$ $\mathrm{TiO}_{2}$ is synthesized by the impregnation method. This study aims to determine the effect of adding $\mathrm{Cu}$ to the $\mathrm{TiO}_{2}$ structure. The 1,3 , and $5 \mathrm{Cu}$ with $\% \mathrm{TiO}_{2}$ dissolved in $50 \mathrm{ml}$ of deionized water, and 3 grams of $\mathrm{TiO}_{2}$ added. The compound is then stirred for 2 hours at $90^{\circ} \mathrm{C}$ and dried in an oven at $110^{\circ} \mathrm{C}$ for 30 minutes. Drying samples were calcined at $500^{\circ} \mathrm{C}$ for 3 hours. $\mathrm{Cu}-\mathrm{TiO}_{2}$ nanocomposites were characterized by XRD, SEM-EDX Mapping, and FTIR. The XRD analysis results show that $\mathrm{Cu}-\mathrm{TiO}_{2}$ nanocomposite has a high level of crystallinity and has an anatase phase structure. The size of $\mathrm{TiO}_{2}$ crystals decreased with $\mathrm{Cu}$ doping and increased from $49.66 \mathrm{~nm}$ to $49.68 \mathrm{~nm}$, with an increase in the composition of the doping mass of $\mathrm{Cu}$. The SEM-EDX Mapping results show that all samples tend to clot, and $\mathrm{Cu}$ dopants evenly distributed on the surface of $\mathrm{TiO}_{2}$. FTIR analysis explained the presence of hydroxyl ions in the sample marked with the appearance of the absorption peak at $1658.78 \mathrm{~cm}^{-1}$ associated with $\mathrm{OH}$ bending of Ti-OH.
\end{abstract}

Keywords: nanocomposite, copper, titanium, dioxide, impregnation 


\section{INTRODUCTION}

Titanium dioxide $\left(\mathrm{TiO}_{2}\right)$ has many advantages compared to other types of semiconductors, including chemical stability, corrosion resistance, and non-toxic [1]. $\mathrm{TiO}_{2}$ has three different phases, namely, anatase, rutile, and brookite. In general, the anatase phase is formed at 300$600^{\circ} \mathrm{C}$, while rutile formed at high temperatures [2,3]. In its use, $\mathrm{TiO}_{2}$ has the limitation of only being stimulated in some parts of the UV light from the sun. Therefore, surface modification of $\mathrm{TiO}_{2}$ with transition metals [4], and non-metal elements [5,6] becomes very important.

Currently, copper metal, $\mathrm{Cu}$, as one of the $\mathrm{TiO}_{2}$ dopants, is the concern of many researchers. To improve the properties of $\mathrm{TiO}_{2}$ can be done by doping with the element $\mathrm{Cu}$. It is caused by high copper conductivity and low cost. Also, copper has a low level of toxicity [7]. Cu can also affect particle size and optical properties of $\mathrm{TiO}_{2}$, and the amount of oxygen on the surface of $\mathrm{TiO}_{2}$ [8]. $\mathrm{Cu}-\mathrm{TiO}_{2}$ has been widely applied in various fields, including environmental remediation, degradation of organic pollutants [9,10], and bacterial disinfection [11].

$\mathrm{Xin}$ et al. [12], synthesized $\mathrm{Cu}-\mathrm{TiO}_{2}$ with dopant variations of $\mathrm{Cu}$ ( 0 to 3 mol\%) made by the sol-gel method. It was found that at $0.06 \%$ mol had many electronic traps, such as the voiding of $\mathrm{O}$ and $\mathrm{Cu}$ (II) ions and compared with pure $\mathrm{TiO}_{2}$, the hydroxyl content on the surface of $\mathrm{Cu}-\mathrm{TiO}_{2}$ increased. Heciak et al. [13] studied the effect of modification procedures and copper precursors on the physicochemical and photoactivity on the formation of useful hydrocarbons from acetic acid. The synthesis of $\mathrm{Cu}-\mathrm{TiO}_{2}$ was carried out by different methods, namely impregnation, mechanical alloying, and photo deposition.

Reddam et al. [14], synthesized modified $\mathrm{TiO}_{2}$ with cations of $\mathrm{Fe}, \mathrm{Mn}$, and $\mathrm{Cu}$. The characterization results confirmed the presence of anatase and rutile phases, and well dispersed on the surface of the catalyst, which was verified by XPS analysis. Mathew et al. [15], synthesized $\mathrm{Cu}-\mathrm{TiO}_{2}$ by the sol-gel method and calcined at a temperature range of $500-700^{\circ} \mathrm{C}$ for antimicrobial applications. The characterization results explained the presence of anatase at a temperature of $500-600^{\circ} \mathrm{C}$, and bandgap energy was obtained $2.8 \mathrm{eV}$. The calcination temperature treatment of $500^{\circ} \mathrm{C}$ was too carried out by Heider et al. [16]. They reported that at calcination temperature of $500^{\circ} \mathrm{C}$, an anatase phase was obtained.

In this study, the impregnation method was used for the synthesis of $\mathrm{Cu}-\mathrm{TiO}_{2}$ nanocomposites. In the process, this method does not transpire anion or cation exchange. The method depends on the metal cation, which becomes a dopant. Queiroz and Barbosa [17] reported that the synthesis of $\mathrm{Cu}-\mathrm{TiO}_{2}$ by the impregnation method could be obtained by anatase phase $\mathrm{TiO}_{2}$. Behnajady and Eskandarloo [18] reported the same thing. Besides, the insertion of dopants by the impregnation method does not change the electronic structure of the catalyst material.

The micro characterization obtained was done by X-ray Diffraction (XRD) and Scanning electron microscopy (SEM) - energy dispersive X-ray (EDX). The functional group investigated by Fourier-transform infrared spectroscopy (FTIR). 


\section{METHOD}

$\mathrm{Cu}-\mathrm{TiO}_{2}$ nanocomposites synthesized using the impregnation method. Copper sulfate, $\mathrm{n} \%$ ( $\mathrm{n}$ $=0,1,3$, and 5) of the weight of $\mathrm{TiO}_{2}$, was dissolved in $50 \mathrm{ml}$ of distilled water as a solution of copper precursors and stirred with magnetic stirrers until homogeneous at room temperature for 30 minutes. After that, $3 \mathrm{~g} \mathrm{TiO}_{2}$ was added to the solution. Subsequently evaporated at $90^{\circ} \mathrm{C}$ for 2 hours while stirring. The sample was then dried in an oven at $110^{\circ} \mathrm{C}$, crushed and calcined at $500^{\circ} \mathrm{C}$ for 3 hours. It is to obtain the anatase phase $\mathrm{TiO}_{2}$ formed in the temperature range $400-500^{\circ} \mathrm{C}$ [19]. Also, the calcination temperature of $500^{\circ} \mathrm{C}$ can induce $\mathrm{OH}$ group deficiencies on the surface [20].

Nanocomposite samples characterized using X-ray diffraction (XRD), scanning electron microscopy (SEM)-energy dispersive X-ray (EDX) Mapping, and Fourier-transform infrared spectroscopy (FTIR).

TABLE 1. Percentage of $\mathrm{Cu}$ and sample labels.

\begin{tabular}{lll}
\hline Sample & \% Cu & Sample Labels \\
\hline $\mathrm{TiO}_{2}$ & $0 \%$ & $\mathrm{TiO}_{2}$ \\
$\mathrm{TiO}_{2}+\mathrm{Cu}$ & $1 \%$ & $1 \%-\mathrm{CTO}$ \\
$\mathrm{TiO}_{2}+\mathrm{Cu}$ & $3 \%$ & $3 \%-$ CTO \\
$\mathrm{TiO}_{2}+\mathrm{Cu}$ & $5 \%$ & $5 \%-$-CTO \\
\hline
\end{tabular}

\section{RESULT AND DISCUSSION}

FIGURE 1 displays the XRD diffraction pattern of $\mathrm{TiO}_{2}$ and $\mathrm{Cu}-\mathrm{TiO}_{2}$. The XRD pattern was obtained from $\mathrm{Cu}$ radiation in the range of angle values $2 \theta$ from $10^{\circ}-80^{\circ}$. The XRD diffraction patterns of $\mathrm{TiO}_{2}$ and $\mathrm{Cu}-\mathrm{TiO}_{2}$ characterized by the presence of diffraction peaks at an angle of $2 \theta=25.3^{\circ} ; 37.0^{\circ} ; 37.8^{\circ} ; 38.6^{\circ} ; 48.1^{\circ} ; 53.9^{\circ} ; 55.1^{\circ} ; 62.7^{\circ} ; 68.8^{\circ} ; 70.3^{\circ} ; 75.1^{\circ}$; and $76.1^{\circ}$ correspond to lattice planes (101), (103), (004), (112), (200), (105), (211), (204), (116), (220), (215) ) and (301), respectively. All patterns assigned to the crystalline phase structure of $\mathrm{TiO}_{2}$, according to (JCPDS no 21-1272) and $\mathrm{Cu}$ doping on $\mathrm{TiO}_{2}$ does not change the shape of the anatase structure of $\mathrm{TiO}_{2}$. The $\mathrm{Cu}^{2+}$ ion may enter to replace $\mathrm{Ti}$ on $\mathrm{TiO}_{2}$ because the ionic radius of $\mathrm{Cu}^{2+}(0.73 \AA)$ is almost the same as the $\mathrm{Ti}^{4+}$ ion $(0.74 \AA)$ [21]. 


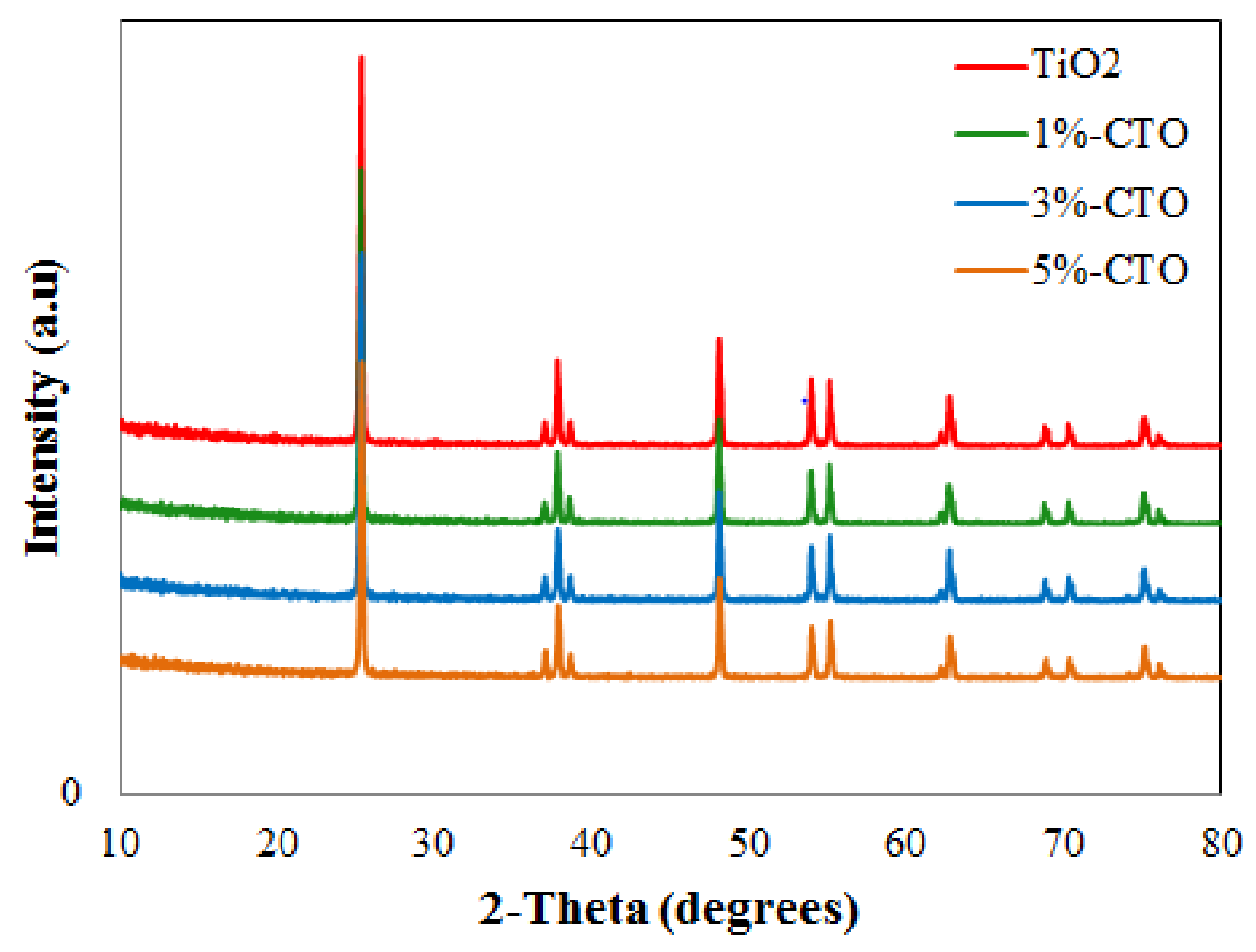

FIGURE 1. XRD patterns of (a) $\mathrm{TiO}_{2}$, (b) $\mathrm{Cu} 1 \%-\mathrm{TiO}_{2}$, (c) $\mathrm{Cu} 3 \%-\mathrm{TiO}_{2}$, and (d) $\mathrm{Cu} 5 \%-\mathrm{TiO}_{2}$.

The average size of the crystallite sample is obtained from the half-width of the full maximum (FWHM) from the highest peak using the Debye-Scherer equation,

$$
t=\frac{k \lambda}{\beta \cos \theta},
$$

where $t$ is the size of a crystal grain, $k$ is the Scherrer constant $(0.9), \lambda$ is the wavelength of $\mathrm{X}$ rays (in $\AA$ ), $\beta$ is the width of half the peak (in radians), and $\theta$ is the Bragg diffraction angle (in radians). The results are shown in TABLE 2.

TABLE 2. Crystalline $\mathrm{Size} \mathrm{TiO}_{2}$ and $\mathrm{Cu}-\mathrm{TiO}_{2}$ nanocomposites.

\begin{tabular}{lllll}
\hline \multirow{2}{*}{ Sample Labels } & \multicolumn{2}{l}{ Lattice Parameters $(\stackrel{\AA}{\mathbf{A}})$} & \multicolumn{1}{c}{$\begin{array}{l}\text { Crystalline } \\
\text { size (nm) }\end{array}$} \\
\cline { 2 - 5 } & $\boldsymbol{a}$ & $\boldsymbol{b}$ & $\boldsymbol{c}$ & 55.88 \\
$\mathrm{TiO}_{2}$ & 3.7798 & 3.7798 & 9.5004 & 49.66 \\
$1 \%-$ CTO & 3.7809 & 3.7809 & 9.5014 & 49.67 \\
$3 \%$-CTO & 3.7798 & 3.7798 & 9.4947 & 49.68 \\
5\%-CTO & 3.7780 & 3.7780 & 9.4900 & \\
\hline
\end{tabular}

The size of the $\mathrm{TiO}_{2}$ crystal was $55.88 \mathrm{~nm}$, and the crystal size was smaller after $\mathrm{Cu}$ doped. The size of the crystals increases with enhancing doping $\mathrm{Cu}$ ions, which are $49.66 \mathrm{~nm} ; 49.47$ $\mathrm{nm}$; and $49.68 \mathrm{~nm}$ respectively for 1\% -CTO; 3\%-CTO; and 5\%-CTO samples. Navas et al. reported that crystal size decreased with an increase in $\mathrm{Cu}$ dopant in $\mathrm{TiO}_{2}$ [22]. Rajamannan et al. reported that as $\mathrm{Cu}$ dopants increased in $\mathrm{TiO}_{2}$, crystal size increased [23]. It explains that $\mathrm{Cu}$ doping can inhibit the growth of grains. 
FIGURE 2 (a-c) shows the results of the characterization using SEM. The results explained that all $\mathrm{Cu}-\mathrm{TiO}_{2}$ samples tended to clot. In FIGURE 2a, small clumps of relatively uniform size appear, and they get more significant with the increasing composition of $\mathrm{Cu}$ dopants, as in FIGURE $2 b$ and 2c. It indicated that $\mathrm{Cu}$ dopants are dispersed on the surface of $\mathrm{TiO}_{2}$. XRD data confirmed this result. Nankya and Kim [24] reported that clumping particles and $\mathrm{TiO} 2$ particle size decreased with the addition of $\mathrm{Cu}$ dopants. It is shown that $\mathrm{Cu}$ doping affects grain growth. FIGURE 3 shows the EDX Mapping image on a 5\%-CTO nanocomposite sample. The elements shown in the image are colored spots. $\mathrm{Cu}$ dopants are evenly distributed on the surface of $\mathrm{TiO}_{2}$. Zaid et al. [25] reported that the dispersed metal element indicated that doping $\mathrm{Cu}$ on the surface of $\mathrm{TiO}_{2}$ by the method used was successful. Also, it shows that the calcination process influences the distribution of elements of $\mathrm{Cu}, \mathrm{O}$, and $\mathrm{Ti}$ that is evenly distributed in $\mathrm{Cu}-\mathrm{TiO}_{2}$, as reported by Tian [20]. This result was also reported by Singh and Dutta [26] with calcination temperatures of $600^{\circ} \mathrm{C}$.

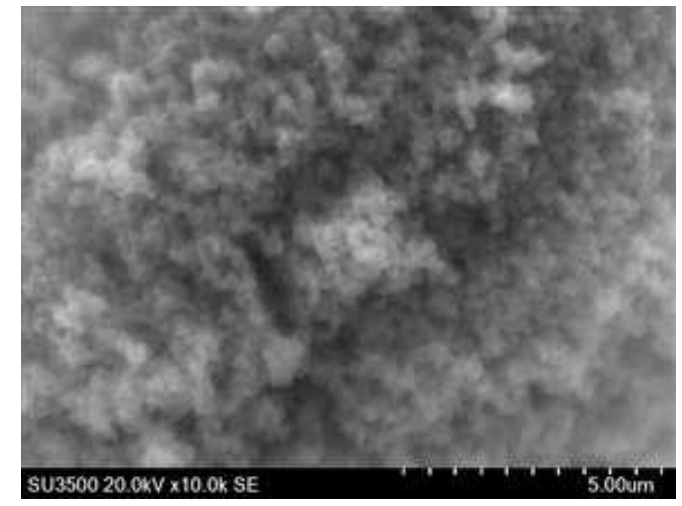

(a)

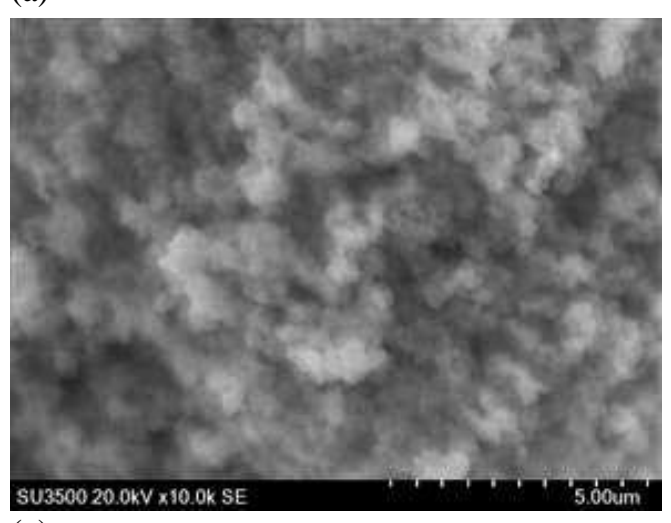

(c)

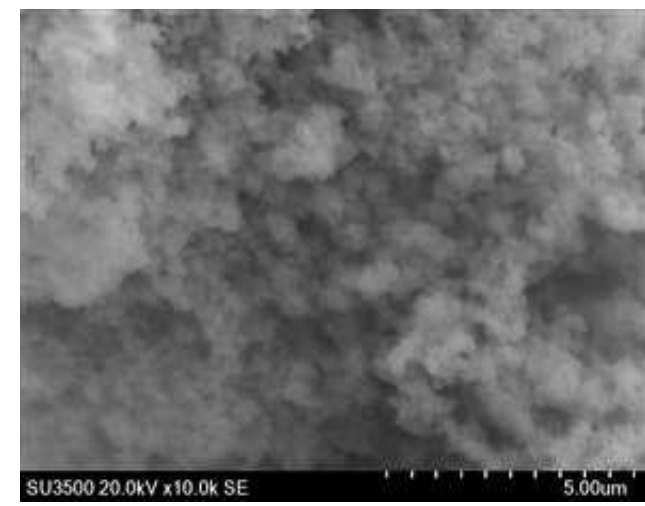

(b)

FIGURE 2. SEM micrographs of (a) 1\%-CTO, (b) 3\%-CTO, and (c) 5\%-CTO 


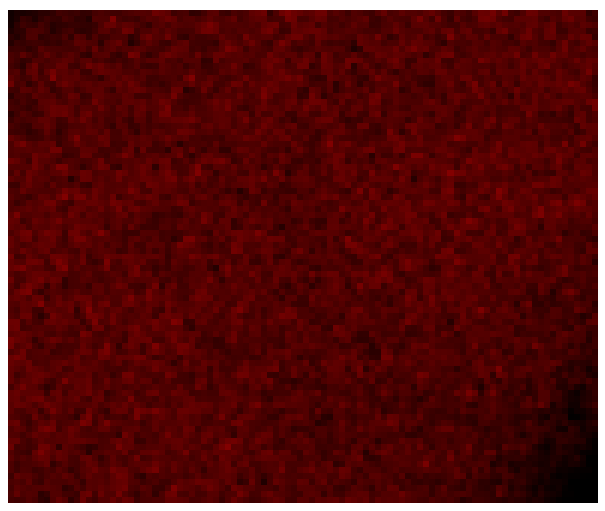

Ti Ka1

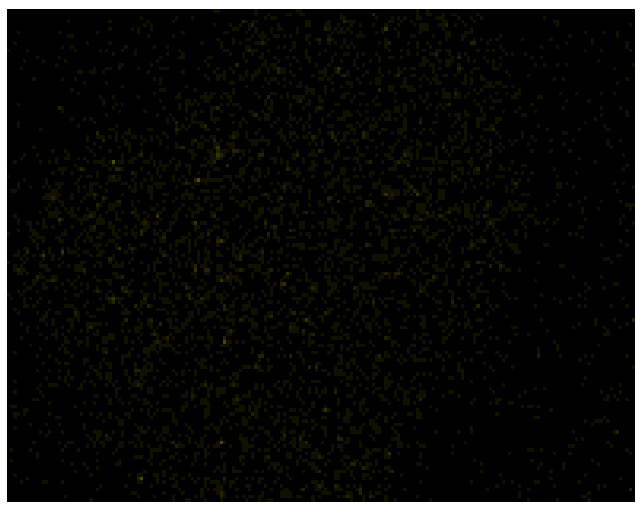

$\mathrm{Cu} \mathrm{Ka} 1$

FIGURE 3. EDX and mapping images of 5\%-CTO

FIGURE 4 shows the FTIR spectrum of $0 \%$-CTO, 1\%-CTO, and 5\% -CTO. In all spectra, the Ti-O-Ti structure appeared in the absorption regions of $669.3 \mathrm{~cm}^{-1}$ and $501.49 \mathrm{~cm}^{-1} ; 677.01$ $\mathrm{cm}^{-1}$ and $516.92 \mathrm{~cm}^{-1}$; and $684.73 \mathrm{~cm}^{-1}$ and $516.92 \mathrm{~cm}^{-1}$, for samples of $0 \%-\mathrm{CTO}, 1 \%-\mathrm{CTO}$, and 5\% -CTO, respectively.. The absorption area of -OH stretching from Ti-OH on the surface of $\mathrm{TiO}_{2}$ and water molecules shifted after $\mathrm{Cu}$ doping, i.e., from $3444.72 \mathrm{~cm}^{-1}$ (0\%-CTO) to $3568.31 \mathrm{~cm}^{-1}$ (1\%-CTO), $3562.52 \mathrm{~cm}^{-1}(5 \%$-CTO). 


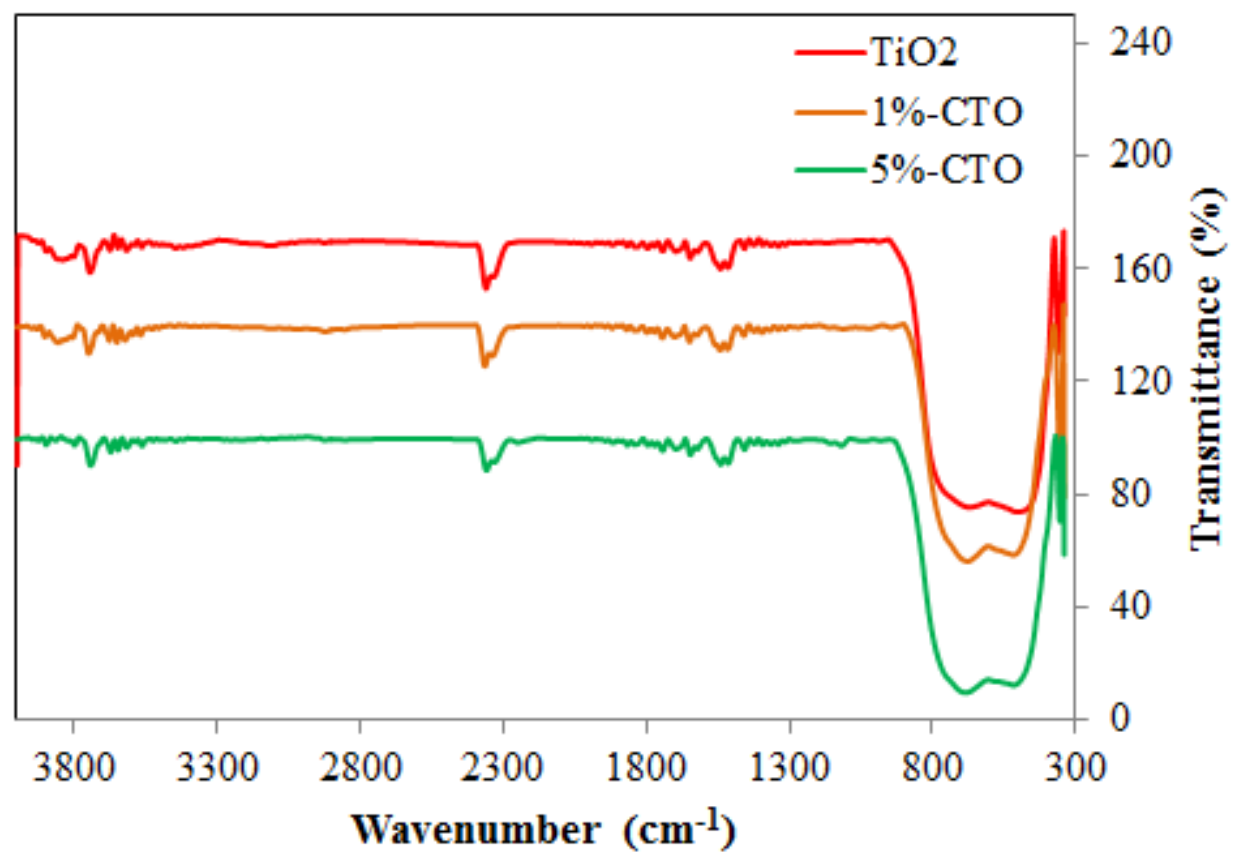

FIGURE 4. FTIR spectra of $\mathrm{TiO}_{2} ; 1 \%$-CTO; and 5\%-CTO.

In $1658.78 \mathrm{~cm}^{-1}$, it was related to the $-\mathrm{OH}$ bending of $\mathrm{Ti}-\mathrm{OH}$ on the surface of $\mathrm{TiO}_{2}$ and the water molecules adsorbed by the catalyst [27]. These results indicate the presence of hydroxyl ions in the sample. It thought that the existence of these peaks is because they are physically adsorbed. The absorption area of $\mathrm{TiO}_{2}$ appears at $600-700 \mathrm{~cm}^{-1}$ and changes with the addition of metals [28].

\section{CONCLUSION}

The $\mathrm{Cu}-\mathrm{TiO}_{2}$ nanocomposites were prepared using the impregnation method. From the observations, it was found that nanocomposites contain $\mathrm{Cu}$ on the surface of $\mathrm{TiO}_{2}$. XRD measurements show that this doping material is an anatase structure phase with a high level of crystallinity and crystalline size ranges from $49.66 \mathrm{~nm}-49.68 \mathrm{~nm}$ and $55.88 \mathrm{~nm}$ for $\mathrm{TiO}_{2}$ without doping. SEM/EDX data show that agglomeration is increasing with the addition of $\mathrm{Cu}$ dopants and $\mathrm{Cu}, \mathrm{Ti}, \mathrm{O}$ elements evenly distributed on the surface of $\mathrm{Cu}-\mathrm{TiO}_{2}$. FTIR data showed that copper, $\mathrm{Cu}$, entered the $\mathrm{TiO}_{2}$ matrix, which was marked by the presence of hydroxyl ions at $1658.78 \mathrm{~cm}^{-1}$.

\section{REFERENCES}

[1] K. Kočí, L. Obalová and Z. Lacný, "Photocatalytic Reduction of $\mathrm{CO}_{2}$ over $\mathrm{TiO}_{2}-\mathrm{Based}$ Catalysts," Chemical Papers, 2008, vol. 62.

[2] J. M. Herrmann, "Heterogeneous Photocatalysis: Fundamentals and Applications To The Removal of Various Types of Aqueous Pollutants," Catalysis Today, 1999, vol. 53. 
[3] N. T. Nolan, "Sol-Gel Synthesis and Characterisation of Novel Metal Oxide Nanomaterials for Photocatalytic Applications," Ph.D. Thesis Dublin Institute of Technology, Dublin, 2010.

[4] K. S. Lin et al., "Synthesis, Characterization, and Application of Anatase-Typed Titania Nanoparticles," J. Environ. Eng. Manage, 2010, vol. 20.

[5] J. Sun, L. Qiao, S. Sun and G. Wang, "Photocatalytic Degradation of Orange G on Nitrogen-Doped $\mathrm{TiO}_{2}$ Catalysts under Visible Light and Sunlight Irradiation," Journal of Hazardous Materials, 2008, vol. 155.

[6] J. Gomes et al., "N-TiO 2 Photocatalysts: A Review of Their Characteristics and Capacity for Emerging Contaminants Removal," Water, 2019, vol. 11.

[7] T. D. Pham and B.K. Lee, " $\mathrm{Cu}$ doped $\mathrm{TiO}_{2} / \mathrm{GF}$ for photocatalytic disinfection of Escherichia coli in bioaerosols under visible light irradiation: Application and mechanism," Applied Surface Science, 2014, vol. 296.

[8] O. Zuas, H. Budiman, "Synthesis of nanostructured copper-doped titania and its properties," Nano-Micro Lett., 2013, vol. 5.

[9] X. Yang et al., "Preparation and photocatalytic performance of $\mathrm{Cu}$-doped $\mathrm{TiO}_{2}$ nanoparticles," Transactions of Nonferrous Metals Society of China, 2015, vol. 25, no. 2 .

[10] I. Ganesh et al., "Preparation and characterization of $\mathrm{Cu}$-doped $\mathrm{TiO}_{2}$ materials for electrochemical, photoelectrochemical, and photocatalytic applications," Applied Surface Science, 2014, vol. 293.

[11] C. Karunakaran et al., "Cu-doped $\mathrm{TiO}_{2}$ nanoparticles for photocatalytic disinfection of bacteria under visible light," Journal of Colloid and Interface Science, 2010, vol. 352, no. 1.

[12] B. Xin et al., "Effect of surface species on $\mathrm{Cu}-\mathrm{TiO}_{2}$ photocatalytic activity," Applied Surface Science, 2008, vol. 254.

[13] A. Heciak et al., "Cu-modified $\mathrm{TiO}_{2}$ photocatalysts for the decomposition of acetic acid with simultaneous formation of $\mathrm{C} 1-\mathrm{C} 3$ hydrocarbons and hydrogen," Applied Catalysis B: Environmental, 2013, vol. 140- 141.

[14] H. A. Reddam et al., "Synthesis of $\mathrm{Fe}, \mathrm{Mn}$ and $\mathrm{Cu}$ modified $\mathrm{TiO}_{2}$ photocatalysts for photodegradation of Orange II," Boletín de la Sociedad Española de Cerámica y Vidrio, 2019, vol. XXX.

[15] S. Mathew et al., "Cu-Doped $\mathrm{TiO}_{2}$ : Visible Light Assited Photocatalytic Antimicrobial Activity," Applied Sciences, 2018, vol. 8.

[16] A. Haider et al., "Synthesis and photocatalytic activity for $\mathrm{TiO} 2$ nanoparticles as air purification," MATEC Web Conf, 2018, vol. 162.

[17] G. A. de Queiroz and C. M. M. de Bezerra Barbosa, "Study of the structural and morphological properties of copper catalysts supported on $\mathrm{Al}_{2} \mathrm{O}_{3}$ and $\mathrm{TiO}_{2}$ synthesized by the impregnation method," revista Matéria, 2019, vol. 24.

[18] M. A. Behnajady and H. Eskandarlo, "Silver and Copper Co-impregnated onto $\mathrm{TiO}_{2-}$ P25 Nanoparticles and its Photocatalutic Activity," Chemical Enginering Journal, 2013, vol. 228. 
[19] I. H. Perez et al., "Ultrasonic Synthesis: Structural, Optical, and Electrical Correlation of $\mathrm{TiO}_{2}$ Nanoparticles," International Journal of Electrochemical Science, 2012, vol. 7.

[20] H. Tian, " $\mathrm{TiO}_{2}$-supported copper nanoparticles prepared via ion exchange for photocatalytic hydrogen production," Master Thesis The University of New South Wales, Australia, Sydney, 2014.

[21] J. Choi, P. Hyunwoong and R. H. Michael, "Combinatorial Doping of $\mathrm{TiO}_{2}$ With Platinum (Pt), Chromium (Cr), vanadium (V), and Nickel (Ni) to Achieve Enhanced Photocatalytic Activity With Visible Irradiation," Journal of Materials Research, 2009, vol. 25 .

[22] J. Navas et al., "Experimental and theoretical study of the electronic properties of $\mathrm{Cu}-$ doped anatase $\mathrm{TiO}_{2}$," Physical Chemistry Chemical Physics, 2014, vol. 16, no. 8.

[23] B. Rajamannan, S. Mugundan, G. Viruthagiri, P. Praveen, and N. Shanmugam, "Linear and nonlinear optical studies of bare and copper doped $\mathrm{TiO}_{2}$ nanoparticles via sol-gel technique," Spectrochimica Acta Part A: Molecular and Biomolecular Spectroscopy, 2014, vol. 118.

[24] R. Nankya and Kyung-Nam Kim, "Sol-Gel Synthesis and Characterization of $\mathrm{Cu}-\mathrm{TiO}_{2}$ Nanoparticles with Enhanced Optical and Photocatalytic Properties," Journal of Nanoscience and Nanotechnology, 2016, vol. 16.

[25] H. F. M. Zaid, C. F. Kait and M. I. A. Mutalib, "Preparation and Characterization Of $\mathrm{Cu}-\mathrm{Fe} / \mathrm{TiO}_{2}$ Photocatalyst For Visible Light Deep Desulfurization,” Malaysian Journal of Analytical Sciences, 2016, vol. 20, no. 4.

[26] R. Singh and S. Dutta, "Synthesis and characterization of copper modified $\mathrm{TiO}_{2}$ photocatalyst with enhanced visible light activity for hydrogen production," Global Conference on Renewable Energy, 2016.

[27] X. T. Zhou, H. J. Ji and X. J. Huang, "Photocatalytic Degradation of Methyl Orange over Metalloporphyrins Supported on $\mathrm{TiO}_{2}$ Degussa P25," Molecules, 2012, vol. 17, no. 2.

[28] P. Yi-Shongkum and J. Tantirungrotechai, "Synthesis of Nitrogen and Iron (III) CoDoped TiO2 for Photodegradation of Methyl Orange Dyes," Pure and Applied Chemistry International Conference, 2011. 
